\title{
O SONHO REALIZADO
}

"Na Grécia Antiga, em uma Praça de Atenas, dois filósofos, durante dias, discutiram, valendo-se de todos os recursos dialéticos, para descobrir o que é mais importante, o sonho ou o belo. Chegaram à conclusão que o sonho é o mais importante, porque só ele é capaz de criar o belo".

Por ocasião da posse da atual diretoria, um dos grandes desafios era a criação de Federadas em cada estado da União, para a FEBRASGO abraçar todo o Brasil, propiciando aos seus associados a luta pela ética e defesa profissional bem como possibilitando sua atualização científica. Este sonho se concretizou com a inauguração da Sociedade de Ginecologia e Obstetrícia do Amapá ocorrida no início de outubro deste ano.

Hoje, sem maiores deslocamentos, os sócios da FEBRASGO, têm a possibilidade de realizar seu programa de educação continuada assim como tomar consciência, debater e encontrar soluções para os problemas da sua região, reunidos na Federada de seu Estado. A FEBRASGO está sempre pronta, seja através da Presidência, das Vice-Presidências e da Secretaria Executiva para assessorá-las em tudo que for necessário.

Estamos todos muito felizes, pois

O SONHO SE TORNOU REALIDADE!

A Diretoria 